\title{
PETROLOGIA DAS ROCHAS METAMORFICAS DA REGIÃO DE SÃO JOSÉ DO RIO PARDO, SP
}

\author{
MARCOS AURÉLIO FARIAS DE OLIVEIRA*
}

\begin{abstract}
The region of São José do Rio Pardo is made up of gneisses, granulites and migmatites of Precambrian age. Two granulitic varieties are described: acid alaskit granulites and pyroxene granulites both of which together with normal gneisses form the paleosoma of migmatites. The pyroxene granulite belongs to a true charnockitic series with the chemical caracteristic of differentiated calc-alkaline rocks. Geochronological determinations indicate an age of about $600 \mathrm{~m}$.y. for the migmatite formation, and somewhat older ages for granulites. Metamorphic differentiation, chiefly through anatexis, producing anhidrous (charnockitic) residual associations, seems to have been the principal factor responsible for the formation of the granulites.
\end{abstract}

INTRODUÇÃo Na região centro-norte do Estado de São Paulo, ocorrem rochas metamórficas pré-cambrianas, que, no mapa geológico de 1962 publicado pelo Instituto Geográfico e Geológico, acham-se agrupadas sob a denominação de Pré-Cambriano não-discriminado. Essa regiåo compreende os municípios paulistas de São José do Rio Pardo, Mococa, Caconde, Tapiratiba, Divinolândia, Vargem Grande do Sul e São Sebastião da Grama. No entanto a área aqui discutida refere-se quase que somente à do município de São José do Rio Pardo.

O trabalho iniciou-se em 1968, com levantamento geológico regional, quando foi observada então a existência de tipos petrográficos interessantes, a merecer um estudo mais pormenorizado. Tratava-se de rochas metamórficas de alto grau com associações mineralogicas características das fácies anfibolito e granulito: gnaisses, migmatitos e granulitos (charnockitos).

A região levantada geologicamente soma cerca de $210 \mathrm{~km}^{2}$ e está localizada entre os meridianos $46^{\circ} 47^{\prime}$ e $46^{\circ} 55^{\prime}$ a oeste de Greenwich e os paralelos $21^{\circ} 30^{\prime}$ e $21^{\circ} 38^{\prime}$ de latitude sul (Fig. 1). A inexistência de mapas na região levou à execução de uma base plani-

Figura 1 - Mapa de localização da área estudada

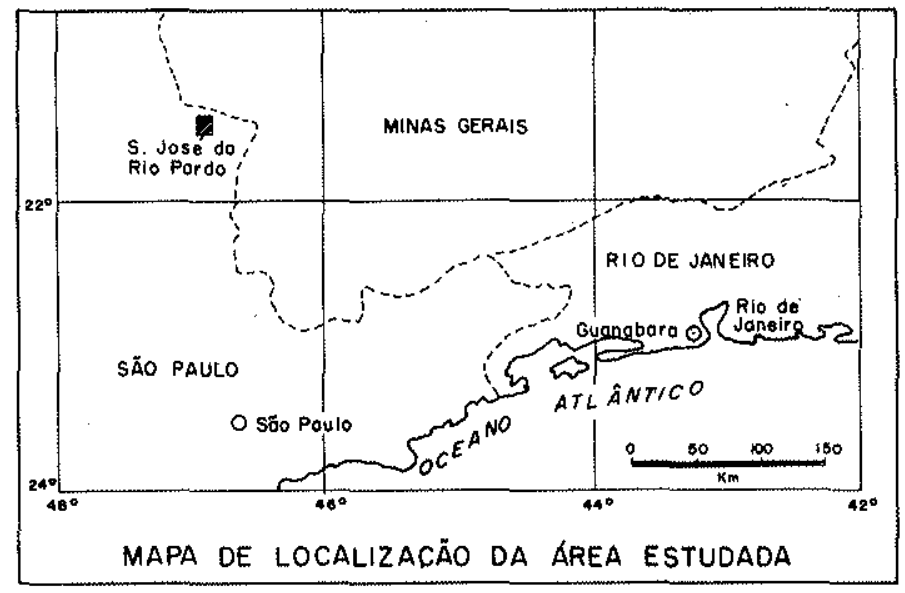

*Instituto de Geociências, Universidade de São Paulo. Caixa Postal 20899, São Paulo 
métrica obtida a partir de fotografias aéreas, na escala de $1: 250000$, da firma Prospec S/A, pelo método da triangulação radial, com controle de campo.

O objetivo inicial do presente trabalho foi a elaboração de mapa geológico regional, visando a estabelecer uma estratigrafia para a área. Posteriormente foram feitos estudos químicos, com o intuito de obter dados que levassem a conclusões sobre a gênese desse complexo metamórfico, principalmente dos granulitos portadores de ortopiroxênios (charnockitos).

A geologia da área é mostrada na Fig. 2. O levantamento, realizado de modo a se anotar o maior número possível de pontos no campo (densidade de observações $=2$ pontos por $\mathrm{km}^{2}$ ), foi dificultado à altura dos contatos, na maioria das vezes transicionais, exigindo, com freqüência, o auxílio da interpretação fotogeológica, especialmente para a delimitação dos corpos charnockíticos.

A área representada pelo mapa geológico é constituída por um conjunto de rochas metamórficas de idade pré-cambriana, enquadradas na ramificação noroeste do Grupo Paraíba, denominada de Araxaídes, por Ebert (1968).

Geologia ESTRUTURAS Os dados coligidos revelam uma estrutura geral orientada na direção NW-SE. As medidas da gnaissificação, para quase todos os tipos litológicos representados na área, variam entre $\mathrm{N} 20 \mathrm{~W}$ e $\mathrm{N} 65 \mathrm{~W}$, com valores dominantes em torno de N40W. As estruturas planares (gnaissificação) mergulham predominantemente para SW, com inversões locais bastante raras. Os angulos de mergulho são suaves, em média da ordem de $30^{\circ}$.

A região não apresenta dobramentos, salvo em escala de afloramento, associados ao migmatitos. A tectônica rígida manifesta-se intensamente através de grande quantidade de falhas gravitacionais e de diaclasamentos associados. $O$ principal sistema de falhas possui direção NE e divide a área em três blocos, sendo que o central desceu relativamente aos blocos noroeste e sudeste, originando assim um autêntico graben. Zonas milonitizadas são comuns ao longo dos planos de falha.

$\mathrm{O}$ fraturamento generalizado dos diversos tipos litológicos favoreceu a formação de grande quantidade de veios de quartzo. Estes ocorrem preferencialmente na direção dos falhamentos (NE), embora a direção E-W também seja comum.

LITOLOGIA Na litologia da área, predominam as rochas gnáissicas, que se constituem, dessa forma, na variedade petrográfica regional. Sua estrutura geral é homogênea (os máficos, principalmente biotita, agrupam-se em leitos isorientados, curtos e descontínuos), ocorrendo também tipos com estrutura bandada.

Os estudos petrográficos permitiram subdividi-los em diversos tipos. Os gnaisses de composição granítica e granodiorítica são os mais comuns e passam a outros através de contatos transicionais. Embora indicando aspecto textural, os tipos porfiroblásticos, verdadeiros augen gnaisses, foram também incluídos na mesma categoria e representados no mapa.

Gnaisse quartzítico é a denominação usada para indicar a variedade em que o quartzo é o mineral mais abundante, chegando a constituir mais de $50 \%$ da rocha, quando então transicionam para quartzitos propriamente ditos. Afloram na porção centro-leste do mapa, nas proximidades do Rio Pardo. Em um dos afloramentos, próximo ao Rio Peixe, camadas decimétricas de quartzito granatífero, cujo acamamento parece confundir-se com a gnaissificação atual, associam-se a granada gnaisses. Ainda dentro desse grupo, estão incluídos alguns corpos de biotita-granada gnaisses. Em geral, são corpos pequenos, que passam gradativamente aos gnaisses mais comuns, face ao desaparecimento da granada. 


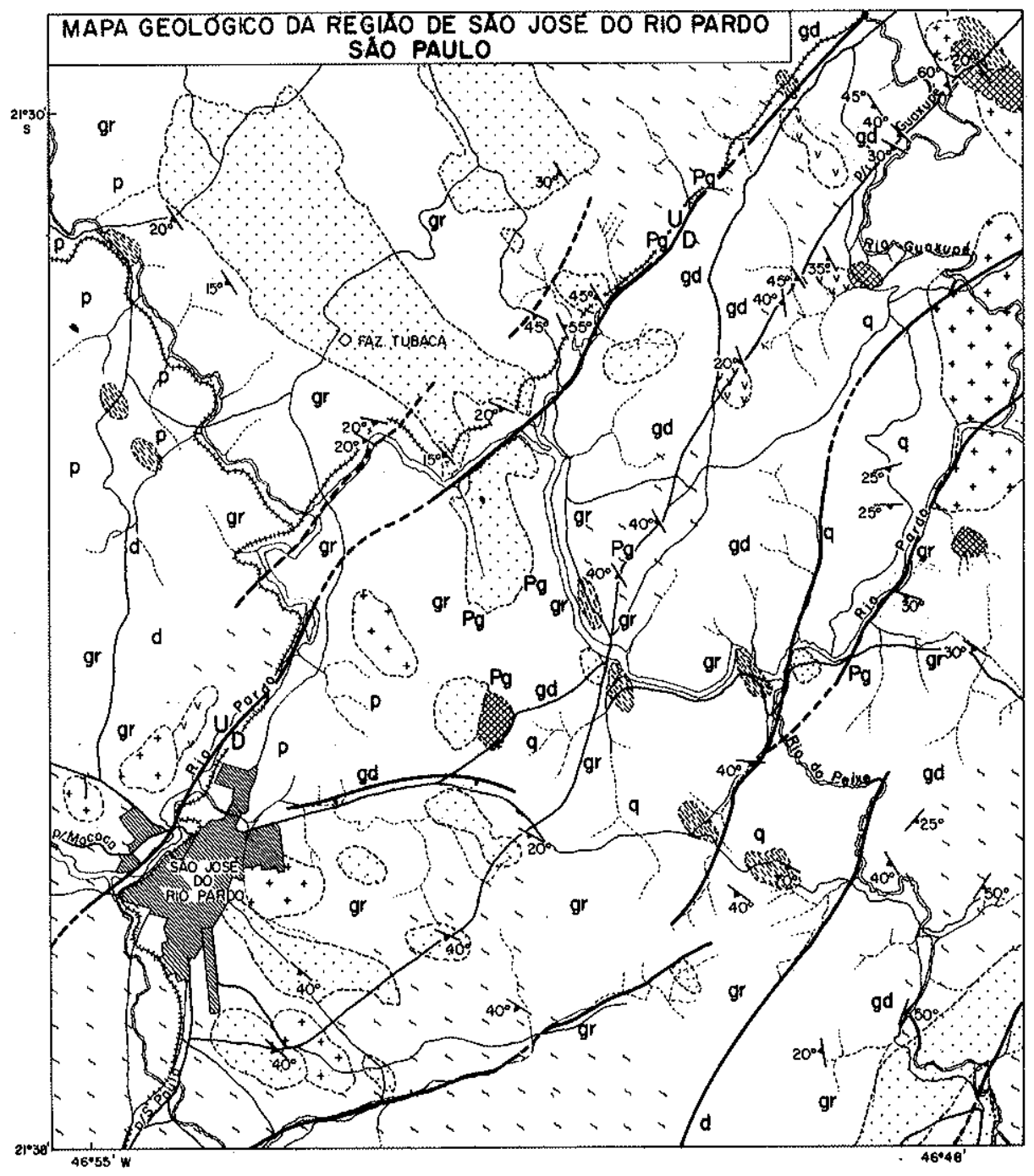

\begin{tabular}{|c|c|c|c|c|}
\hline & Gnaisses: & $+++_{+}^{+}$ & Gronuktos aloskíticos & Contato aproximado \\
\hline gr & groníticos & $\because \because \because$ & Hiperstènio gramulitos (Charnockitos) & $40^{\circ}$ ไ Direçao e mergulho da gnoiss- \\
\hline gd & granodiariticos & {$\left[\begin{array}{ll}v \\
v & v \\
v\end{array}\right.$} & Anfibolitos & Falha verificada \\
\hline d & dioríticos & 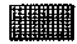 & $\begin{array}{r}\text { Rochas calco- silicáticos (piroxenitos } \\
\text { e gronada piroxenitos) }\end{array}$ & \\
\hline$p$ & porfiroblásticos & $\mathrm{Pg}$ & Pegmatitos & Estrodas e cominhos principais \\
\hline$q$ & quortzíticos & & M.A.F de OLIVEIRA & Ferr \\
\hline (1) & $\begin{array}{l}\text { com granada } \\
\text { (kinzigitos) }\end{array}$ & & ESCALA & Alio a drenagem \\
\hline$\therefore$ & Migmatitos & & ${ }^{1}{ }^{2} \mathrm{~km}$ & Cidode \\
\hline
\end{tabular}

Figura 2 - Mapa geológico da região de São José do Rio Pardo, SP 
Os migmatitos aparecem principalmente nas porções nordeste e sudoeste da carta. Orientam-se concordantemente à gnaissificação regional NW e apresentam estrutura bandada, distinta ou irregular. Neles, distinguem-se duas partes: uma hospedeira, paleossoma, representado por gnaisses escuros e granulitos, e outra intercalada à primeira, o neossoma, que pode ser granítico, granodiorítico, quartzo-diorítico ou pegmatóide.

Estruturas dobradas dentro dos migmatitos são muito freqüentes, podendo, em muitos pontos, constituir estruturas ptigmáticas, com as bandas graníticas dobradas e retorcidas cortando as bandas gnáissicas. Da mesma forma, lentes, bolsas ou "buchos" formados por anfibolito ou por agregados biotíticos são também comuns.

A migmatização não se restringe às áreas assinaladas no mapa geológico. Ela se generaliza em todas as escalas e intensidades, tornando assim muito dificil a delimitação das litologias, especialmente a separação entre os gnaisses e os verdadeiros migmatitos.

Granulitos róseos, alaskíticos, constituem corpos irregulares de pequenas dimensões, bem como intercalações menores distribuídas por toda a área estudada. Podem mesmo constituir bandas claras dentro de gnaisses bandados ou migmatitos. São rochas quartzo-feldspáticas, com orientação ditada pelo alongamento de grãos de quartzo. Em muitos locais são verdadeiros aplitos, muito semelhantes aos descritos por Quensel (1951) em seu trabalho sobre as rochas charnockíticas da Suécia.

Os hiperstênio granulitos ou charnockitos ocorrem em toda a área sob a forma de corpos lenticulares, alongados na direção NW-SE, ou de pequenos corpos tabulares. Os maiores não possuem contatos bem definidos com as rochas encaixantes, existindo quase sempre uma zona de transição constituída por intercalações de gnaisses biotíticos e charnockitos. As concentrações de biotita nessa zona transicional parecem corresponder a residuos de máficos charnockíticos transformados, ocorrendo em uma região de contato onde as trocas metassomáticas levaram também à venulação neossomática e conseqüente formação de rocha intermediária e gradacional. Os corpos tabulares são poucos e mostram contatos mais nítidos com as rochas vizinhas. Não apresentam padrão direcional definido, sendo ora concordantes com a gnaissificação regional, ora discordantes, cortando-a segundo as direções principais de fraturamento NE.

As rochas charnockíticas formam pequenos corpos, com o maior deles atingindo 8 $\mathrm{km}$ de comprimento por $2 \mathrm{~km}$ de largura (Fazenda Tubaca). Evidenciam certa orientação, sendo a direção de gnaissificação concordante com a direção dos gnaisses regionais. Típos intermediários constituem a maioria dessas rochas. Os tipos básicos são normalmente representados por corpos tabulares, intercalados nos charnockitos intermediários ou nos gnaisses. Formam também um pequeno corpo circular, associado a piroxenito, na parte central do mapa geológico (amostra 180-C, Fig. 3). Os tipos ácidos são raros e tendem a confundir-se com os granulitos alaskíticos.

Os anfibolitos são pouco abundantes e ocorrem normalmente intercalados aos migmatitos.

Sob a denominação de calcio-silicáticas, acham-se agrupadas rochas de antecedentes calcários, tendo piroxenitos e granada-piroxenitos como os tipos petrográficos mais comuns. Essas rochas possuem distribuição restrita e formam quatro pequenas lentes, com a maior delas localizada no extremo nordeste do mapa, associada a calcários metamórficos.

Pelo exposto, pode-se concluir que os contatos entre as litologias descritas são quase sempre gradacionais, inexistindo assim qualquer possibilidade de traçar-se um limite exato entre tipos de rocha confinantes. Constituem exceção as lentes calcio-silicáticas e alguns corpos tabulares de charnockitos básicos. Nos demais casos, o que se tem é a passagem de um tipo litológico a outro, pelo enriquecimento ou empobrecimento em determinados minerais, ou por intercalações dos dois tipos de rochas confinantes. 


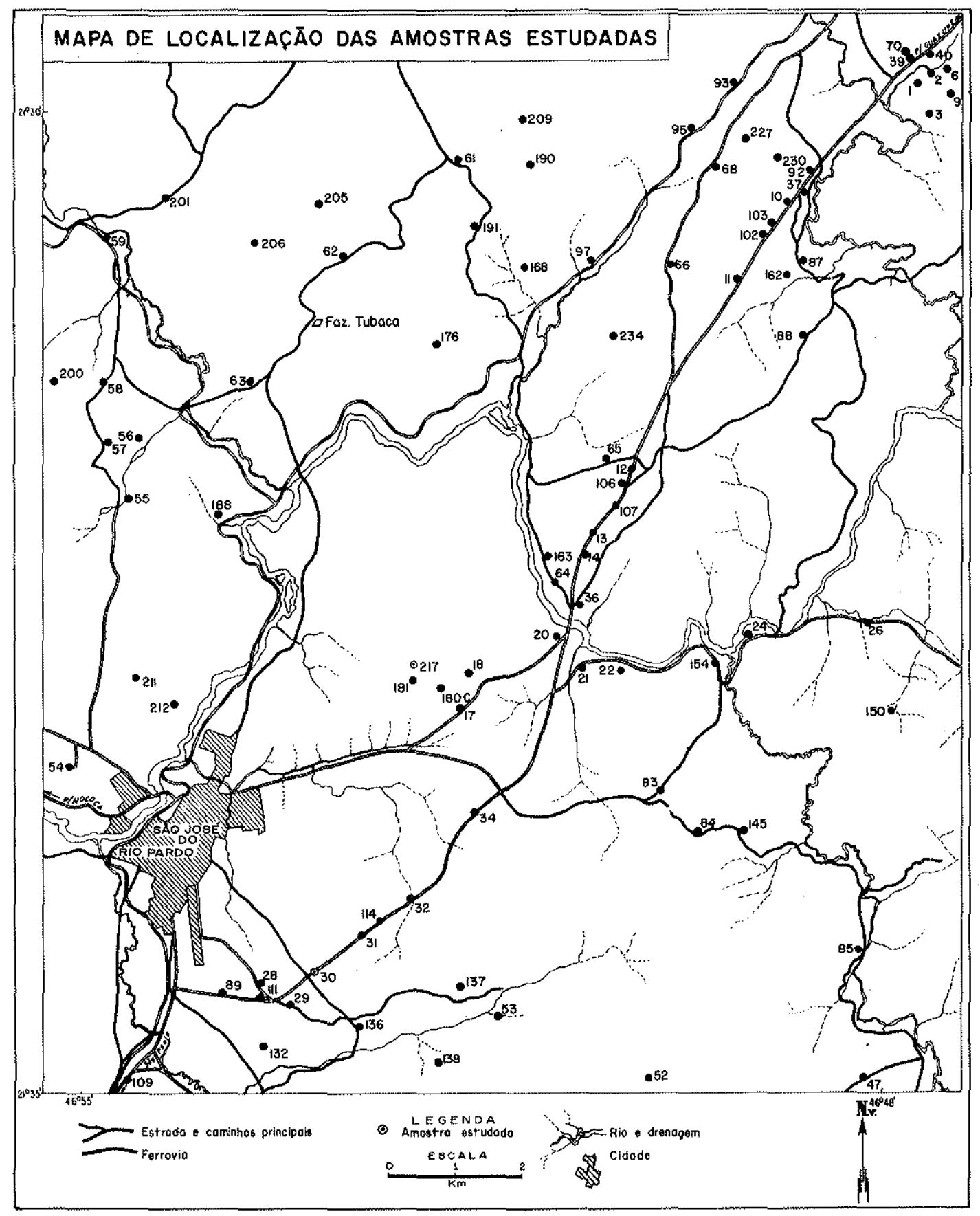

Figura 3 - Mapa de localização das amostras estudadas 
Petrografia GNAISSES Os gnaisses apresentam uma composição mineralógica relativamente simples, sendo quartzo e feldspato os constituintes predominantes, perfazendo $50 \%$ ou mais em volume das amostras. Seguem-se, em importância, a biotita, a hornblenda e o diopsídio. São rochas leucocráticas cujas cores variam de cinza-clara a rosa. A estrutura gnáissica é definida pelos máficos, agrupados e orientados subparalelamente em linhas descontínuas, ou, em alguns casos, em bandas. A textura é do tipo granoblástica ou granolepidoblástica, com a maioria dos constituintes xenoblásticos. A textura porfiroblástica está raramente presente. Em quase todas as amostras, há evidências de milonitização, com posterior recristalização. Essas evidências acham-se representadas por deformações, fraturamentos e microgranulação dos grãos de quartzo e feldspatos, principalmente.

Análises modais de algumas amostras, constantes da Tab. 1, permitem agrupá-las em vários tipos, desde granítico até diorítico, utilizando-se, mutatis mutandis, a nomenclatura proposta por Streckeisen (1967) para as rochas ígneas. Os tipos granítico e granodiorítico são os dominantes; o primeiro tem quartzo e pertita como componentes principais e o último quartzo e plagioclásio (termo oligoclásio-andesina). Há também variedades muito ricas em quartzo, que poderiam ser classificadas como quartzitos feldspáticos. Os tipos porfiroblásticos corresponderiam a tipos de composição adamellítica, sendo os porfiroblastos de feldspato potássico e exibindo dimensões centimétricas. Esses porfiroblastos são, muitas vezes, poiquiloblásticos, com cristais de biotita como inclusões.

Tabela I - Análises modais de gnaisses

\begin{tabular}{lcccccccc}
\hline & 84 & 66 & 68 & 188 & 227 & 200 & 55 & 52 \\
\hline \hline Quartzo & 54,3 & 39,4 & 27,5 & 23,1 & 19,1 & 1,9 & - & - \\
Feldspato & 1,8 & 1,2 & 1,9 & 2,0 & - & - & 8,9 & - \\
$\quad$ potássico & - & - & - & 34,6 & - & 55,1 & 15,4 & - \\
Pertita & 30,4 & 49,0 & 28,0 & 29,8 & 68,3 & 34,7 & 47,7 & 47,1 \\
Plagioclásio & 9,2 & 5,9 & 29,5 & - & 4,9 & - & - & - \\
Antipertita & pr & - & - & 3,3 & - & 1,3 & - & - \\
Mirmequita & 0,1 & - & 0,5 & - & 0,5 & 4,1 & 3,9 & 29,4 \\
Hornblenda & 3,4 & - & 0,5 & 6,1 & - & 1,0 & 17,5 & 10,9 \\
Biotita & - & 3,5 & 8,3 & - & 5,9 & - & 1,6 & 5,0 \\
Clinopiroxênio & 0,2 & 0,5 & 3,1 & 0,7 & 0,6 & 1,7 & 3,1 & 4,8 \\
Opacos & 0,1 & 0,1 & 0,7 & 0,1 & 0,2 & 0,1 & 1,2 & 1,1 \\
Apatita & $\mathrm{pr}$ & 0,1 & $\mathrm{pr}$ & 0,1 & $\mathrm{pr}$ & 0,1 & 0,2 & - \\
Zircão & - & - & - & - & 0,5 & - & - & - \\
Titanita & - & - & $\mathrm{pr}$ & - & - & - & 0,5 & 0,7 \\
Epídoto & 0,5 & 0,3 & - & 0,2 & - & - & - & 1,0 \\
Sericita & & - & & & & & &
\end{tabular}

$\begin{aligned} \mathrm{pr} & =\text { presente } & & \\ 84 & =\text { Gnaisse granodioritico } & 227 & =\text { Gnaisse quartzo dioritico } \\ 66 & =\text { Gnaisse quartzo diorítico } & 200 & =\text { Gnaisse monzonítico } \\ 68 & =\text { Gnaisse granodioritico } & 55 & =\text { Gnaisse monzo-diorítico } \\ 188 & =\text { Gnaisse granítico } & 52 & =\text { Gnaisse dioritico }\end{aligned}$

Os feldspatos potássicos presentes são o microclínio - com geminação em grade bem pronunciada em alguns tipos e incipiente em outros - e a pertita. Esta forma grãos que medem, em média, $2 \mathrm{~mm}$. Há casos em que a quantidade de albita presente na estrutura pode perfazer mais da metade do indivíduo hospedeiro (mesopertita). 
O plagioclásio é do tipo sódico, com o teor de anortita variando entre 20 e $34 \%$, isto é, de oligoclásio e andesina sódica. Apresenta-se comumente sem geminação, em grãos xenomórficos equidimensionais e límpidos. Pode aparecer na forma de antipertita com quantidades de feldspato potássico incluso, nunca superiores a $10 \%$ do hospedeiro.

A biotita apresenta-se em grãos que medem cerca de $1 \mathrm{~mm}$ de comprimento, com largura bem inferior a essa dimensão; são, portanto, grãos bem alongados e orientados paralelamente à gnaissificação das rochas. Já a hornblenda apresenta granulação que varia entre 0,5 a $2,0 \mathrm{~mm}$ e os grãos prismáticos estão orientados paralelamente à gnaissificação. O pleocroísmo desse material é intenso e característico dos tipos mais comuns.

Clinopiroxênio constitui grãos xenomórficos de contornos irregulares, com diâmetro médio de $1 \mathrm{~mm}$ e levemente plecróicos. Mostra, às vezes, uma lamelação muito fina $\mathrm{e}$ está constantemente alterado em hornblenda verde-clara, biotita, opacos, epídoto e titanita. Apresenta as seguintes propriedades ópticas: $Z \Lambda_{c}=42^{\circ}, N_{Z}=1,722 \ell N_{X}=1,696$, $2 V_{Z}=59^{\circ}$, o que, segundo Hess (1949), indica os termos salita e ferrosalita da série diopsídio-hedenbergita.

Quatro amostras constantes da Tab. I foram analisadas quimicamente são elas: a 55, um gnaisse monzo-diorítico, a 227, um gnaisse quartzo-diorítico, a 188, um gnaisse granítico e a 200, um gnaisse sienítico ou monzonítico. As análises químicas, juntamente com as normas CIPW e peso específico das amostras, são apresentadas na Tab. II.

Tabela II - Análises modais e normas moleculares de gnaisses

\begin{tabular}{lrrrrrrrrrr}
\hline & 227 & 188 & \multicolumn{1}{c}{200} & \multicolumn{1}{c}{55} & & 227 & 188 & 200 & 55 \\
\hline $\mathrm{SiO}_{2}$ & 72,46 & 70,12 & 60,62 & 54,34 & $\mathrm{Qz}$ & 26,34 & 29,64 & 1,92 & - \\
$\mathrm{TiO}_{2}$ & 0,33 & 0,60 & 0,10 & 0,76 & $\mathrm{Or}$ & 5,56 & 23,35 & 43,37 & 27,24 \\
$\mathrm{Al}_{2} \mathrm{O}_{3}$ & 15,39 & 13,66 & 18,15 & 18,36 & $\mathrm{Ab}$ & 51,35 & 29,34 & 34,06 & 36,15 \\
$\mathrm{Fe}_{2} \mathrm{O}_{3}$ & 0,08 & 2,42 & 3,08 & 5,18 & $\mathrm{An}$ & 11,95 & 7,78 & 9,73 & 17,24 \\
$\mathrm{FeO}$ & 0,14 & 2,53 & 2,89 & 4,33 & $\mathrm{Di}$ & 1,97 & - & 3,46 & 5,19 \\
$\mathrm{MnO}$ & 0,21 & 0,08 & 0,10 & 0,18 & $\mathrm{Hy}$ & 1,70 & 3,55 & 5,67 & 0,66 \\
$\mathrm{MgO}$ & 1,02 & 0,67 & 1,17 & 2,09 & $\mathrm{OI}$ & - & - & - & 3,46 \\
$\mathrm{CaO}$ & 2,90 & 1,56 & 1,95 & 4,95 & $\mathrm{Co}$ & - & 0,61 & - & - \\
$\mathrm{Na}_{2} \mathrm{O}$ & 6,08 & 3,45 & 4,01 & 4,30 & $\mathrm{Il}$ & 0,61 & 1,06 & 0,15 & 1,52 \\
$\mathrm{~K}_{2} \mathrm{O}$ & 0,96 & 3,95 & 7,32 & 4,64 & $\mathrm{Mt}$ & - & 3,48 & 4,41 & 7,42 \\
$\mathrm{H}_{2} \mathrm{O}^{+}$ & 0,36 & 0,54 & 0,30 & 0,49 & $\mathrm{Ap}$ & - & - & - & 0,34 \\
$\mathrm{H}_{2} \mathrm{O}^{-}$ & 0,02 & 0,20 & 0,23 & 0,19 & $\mathrm{Hm}$ & - & - & 0,32 & - \\
$\mathrm{P}_{2} \mathrm{O}_{5}$ & 0,03 & 0,03 & 0,06 & 0,23 & & & & & \\
$\mathrm{Total}$ & 99,98 & 99,81 & 99,98 & 100,04 & & & & & \\
$\mathrm{Peso}^{\text {específico }}$ & 2,68 & 2,67 & 2,65 & 2,76 & & & & & \\
\hline
\end{tabular}

Analista: Raphael Hypólito, DMP-IG

GNAISSES GOM GRANADA (kinzigitos) Os gnaisses granatíferos são rochas de coloração cinza-escura, granulação média de $2 \mathrm{~mm}$, estrutura gnáissica, e exibindo, às vezes, venulação quartzo-feldspática. A textura é granoblástica ou porfiroblástica, sendo que, nesse último caso, as granadas constituem porfiroblastos. Há evidências de uma milonitização incipiente que provocou fraturamentos e deformações em quase todos os minerais.

As análises modais de algumas amostras são apresentadas na Tab. III. Pode-se observar que as quantidades de quartzo presentes são sempre elevadas em todas as amostras, sendo superior a $70 \%$ no exemplar 145 , que poderia, assim, ser denominado de quartzito granatífero. De um modo geral, os tipos petrográficos são muito semelhantes. 
Tabela III - Análises modais de kinzigitos

\begin{tabular}{lcccccc}
\hline Amostras & 83 & 58 & 40 & 56 & 154 & 145 \\
\hline \hline Quartzo & 29,8 & 36,6 & 32,5 & 32,2 & 33,7 & 74,7 \\
Feldspato & 0,9 & 0,4 & - & 0,4 & 5,4 & 9,6 \\
$\quad$ potássico & 3,9 & - & - & - & - & - \\
Pertita & 12,1 & 17,8 & 18,7 & 42,7 & 21,0 & 1,0 \\
Plagioclásio & 4,6 & - & 7,0 & 0,5 & 2,4 & - \\
Antipertita & 0,1 & - & - & 0,5 & 0,7 & - \\
Mirmequita & 34,4 & 12,0 & 30,9 & 10,5 & 19,6 & 3,6 \\
Biotita & 14,0 & $-8,8$ & 10,7 & 11,2 & 16,4 & 8,8 \\
Granada & - & 10,2 & - & - & - & - \\
Sillimanita & - & 8,6 & - & - & - & - \\
Cordierita & - & 2,0 & - & 0,9 & 0,4 & 1,6 \\
Sericita & 0,1 & 3,6 & 0,1 & 1,0 & 0,4 & 0,3 \\
Opacos & - & - & 0,1 & - & - & - \\
Apatita & 0,1 & pr & - & 0,1 & pr & - \\
Zircão & - & - & - & - & - & 0,4 \\
Rutilo & - & pr & - & - & - & - \\
Espinélio & & & & &
\end{tabular}

$\mathrm{pr}=$ presente

A denominação de kinzigitos para essas rochas está sendo empregada de acordo com a definição dada por Mehnert (1968), que caracteriza rochas semalhantes em regiões migmatizadas da Alemanha (Kinzig).

Entre os componentes mineralógicos, destaca-se a granada, presente em todos os. tipos em quantidades variáveis. Seus cristais rosados medem em média $2 \mathrm{~mm}$ de diâmetro $\mathrm{e}$, muitas vezes, constituem porfiroblastos com tendências idiomórficas e poiquiloblásticas, sendo quartzo, biotita e opacos (magnetita) as inclusões mais comuns. Associa-se à biotita e, no decorrer do seu processo de formação, empurrou e deformou as placas desse mineral à sua volta.

Dados obtidos para algumas propriedades fisicas, índice de refração $(n)$, peso específico $(D)$ e parâmetro da cela unitária $\left(a_{0}\right)$, de seis granadas, são fornecidos a seguir:

$\begin{array}{lcccccc} & 83 & 58 & 56 & 40 & 154 & 163 \\ n & 1,791 & 1,803 & 1,803 & 1,803 & 1,795 & 1,803 \\ D & 3,986 & 4,048 & 4,016 & 4,054 & 4,031 & 4,013 \\ a_{0}(\AA) & 11,52 & 11,52 & 11,50 & 11,52 & 11,50 & 11,51\end{array}$

Esses valores projetados nos diagramas de Sriramadas (1957), que correlacionam o índice de refração e o parâmetro da cela unitária com a composição química das granadas, indicam termos formados por almandina (60\% aproximadamente) e piropo, com pequenas quantidades dos componentes espessartita, grossulária e andradita.

Sillimanita e cordierita foram encontradas em um único afloramento de kinzigito, correspondente à amostra 58 .

O plagioclásio é uma andesina sódica com teores de anortita entre 30 e $44 \%$. Antipertita está presente em pequenas quantidades em algumas rochas, o mesmo acontecendo com o feldspato potássico (ortoclásio).

Da Tab. IV, constam a análise química da amostra 83 de um granada-cordierita granulito, fornecida por Eskola (1952) e a média de 6 análises de kinzigitos extraída de Simonen (1953). 
Tabela IV - Análise química de kinzigito

\begin{tabular}{lrrr}
\hline & $83^{*}$ & $\mathrm{~A}$ & \multicolumn{1}{c}{$\mathrm{B}$} \\
\hline \hline $\mathrm{SiO}_{2}$ & 57,45 & 59,5 & 59,64 \\
$\mathrm{TiO}_{2}$ & 0,80 & 0,2 & 0,75 \\
$\mathrm{Al}_{2} \mathrm{O}_{3}$ & 15,58 & 16,9 & 17,42 \\
$\mathrm{Fe}_{2} \mathrm{O}_{3}$ & 4,31 & 3,3 & 2,42 \\
$\mathrm{FeO}$ & 8,70 & 9,9 & 5,84 \\
$\mathrm{MnO}$ & 0,21 & 0,2 & 0,13 \\
$\mathrm{MgO}$ & 4,14 & 4,2 & 3,82 \\
$\mathrm{CaO}$ & 2,57 & 1,9 & 1,82 \\
$\mathrm{Na}_{2} \mathrm{O}$ & 2,64 & 1,4 & 1,98 \\
$\mathrm{~K}_{2} \mathrm{O}$ & 3,02 & 1,8 & 3,32 \\
$\mathrm{H}_{2} \mathrm{O}^{+}$ & 0,40 & 0,3 & 2,23 \\
$\mathrm{H}_{2} \mathrm{O}^{-}$ & 0,16 & - & - \\
$\mathrm{P}_{2} \mathrm{O}_{5}$ & - & 99,9 & 0,04 \\
$\mathrm{Total}^{\mathrm{Peso}}$ & 99,98 & - & 99,41 \\
específico & 2,95 & & - \\
\hline
\end{tabular}

*Analista: Raphael Hypólito, DMP-IG

83 = Gnaisse kinzigitico de São José do Rio Pardo

$\mathrm{A}=$ Granada-cordierita-granulito de Lapland, Finlândia (Eskola, 1952)

$\mathrm{B}=$ Média de 6 kinzigitos (Simonen, 1953)

MIGMATITOS Os migmatitos são rochas macroscopicamente compostas, consistindo em duas partes petrograficamente diferentes: o paleossoma, representado pelos gnaisses regionais e granulitos, e o neossoma, material granitóide ou pegmatóide.

As bandas leucossomáticas são rochas sem orientação, exibindo uma textura granoblástica xenoblástica, por vezes milonítica com os grãos minerais deformados, fraturados e rodeados por material de granulação mais fina (textura em moldura). $O$ fabric é equigranular de granulação média, com exceção dos tipos pegmatóides. As variedades de composição granodiorítica e quartzo-diorítica predominam no canto nordeste da área, ao passo que as graníticas são mais comuns no canto sudoeste. Nas primeiras, plagioclásio com teores de anortita entre 20 e $30 \%$, antipertita e quartzo são os constituintes siálicos mais importantes e biotita, hornblenda e clinopiroxênio (salita) são os ferromagnesianos principais; nas últimas, quartzo, pertita e microclínio somam quase sempre $90 \%$ do volume das amostras. Leucossoma pegmatóide, embora menos abundante, distribui-se amplamente e constitui-se, em geral, de microclínio micropertita, plagioclásio (oligoclásio), quartzo e biotita.

O melanossoma é constituído principalmente por anfibolitos ou rochas dioríticas e, menos comumente, pelas biotititos. A composição essencial dos anfibolitos ou dioritos resume-se em plagioclásio com teores de anortita entre 25 e $40 \%$, hornblenda e biotita, sendo a textura granoblástica ou, por vezes, nematoblástica.

O limite entre o leucossoma e o melanossoma é normalmente nítido, chamando atenção, em muitos pontos, as formas convexas do leucossoma voltadas para o melanossoma, fato mencionado por Mehnert (1968) como sendo comum a todas as regióes migmatizadas. 
GRANULITOS ALASKÍTICOS Os granulitos alaskíticos são rochas granulares róseas compostas essencialmente por quartzo, mesopertita, microclínio e plagioclásio $\mathrm{An}_{20}$, e praticamente desprovidas de minerais ferromagnesianos. Ostentam textura granoblástica em que grãos maiores, xenomórficos e alongados de quartzo e pertita intercalam-se em material de granulação mais fina, composto de quartzo, microclínio pertita e plagioclásio (textura flaser).

A análise modal de uma amostra típica é apresentada na Tab. V. Sua composição mineralógica corresponde, a grosso modo, à dos granitos, enquanto que a composição química guarda mais semelhança com a dos granitos aplíticos.

Tabela V - Análise modal, análise química e norma molecular de uma amostra de granulito alaskítico

\begin{tabular}{|c|c|c|c|c|c|c|}
\hline & & & & & & \\
\hline & 30 & & $30^{*}$ & A & & 30 \\
\hline Quartzo & 35,3 & $\mathrm{SiO}_{2}$ & 74,06 & 73,72 & $\mathrm{Qz}$ & 26,76 \\
\hline $\begin{array}{l}\text { Microclínio- } \\
\text {-pertita }\end{array}$ & 2,3 & $\mathrm{TiO}_{2}$ & 0,19 & 0,20 & Or & 25,02 \\
\hline Pertita & 34,3 & $\mathrm{Al}_{2} \mathrm{O}_{3}$ & 13,60 & 13,58 & $\mathrm{Ab}$ & 42,44 \\
\hline Plagioclásio & 24,1 & $\mathrm{Fe}_{2} \mathrm{O}_{3}$ & 0,73 & 0,60 & An & 1,95 \\
\hline Mirmequita & 2,9 & $\mathrm{FeO}$ & 0,55 & 1,12 & $\mathrm{Di}$ & 2,00 \\
\hline Hornblenda & 0,4 & $\mathrm{MnO}$ & 0,03 & 0,02 & Il & 0,30 \\
\hline Biotita & 0,1 & $\mathrm{MgO}$ & 0,28 & 0,14 & Mt & 1,16 \\
\hline Clorita & $\mathrm{pr}$ & $\mathrm{CaO}$ & 1,09 & 1,04 & & \\
\hline Apatita & 0,1 & $\mathrm{Na}_{2} \mathrm{O}$ & 5,02 & 2,43 & & \\
\hline Zircão & $\mathrm{pr}$ & $\mathrm{K}_{2} \mathrm{O}$ & 4,20 & 6,87 & & \\
\hline Opacos & 0,5 & $\mathrm{H}_{2} \mathrm{O}^{+}$ & 0,16 & 0,18 & & \\
\hline & & $\mathrm{H}_{2} \mathrm{O}^{-}$ & 0,04 & 0,09 & & \\
\hline & & $\mathrm{P}_{2} \mathrm{O}_{5}$ & 0,10 & - & & \\
\hline & & Total & 100,05 & 99,99 & & \\
\hline & & $\begin{array}{l}\text { Peso } \\
\quad \text { específico }\end{array}$ & 2,61 & & & \\
\hline
\end{tabular}

*Analista: Raphael Hypólito, DMP-IG

30 = Granulito alaskitico de São José do Rio Pardo

$\mathbf{A}=$ Granito aplitico do distrito de Varberg, Suécia (Quensel, 1951)

HIPERSTÊNIO GRANULITOS (charnockitos) Os hiperstênio-granulitos da região de São José do Rio Pardo apresentam consideráveis variações nos teores de sílica, o que permitiu agrupá-los em tipos ácidos, intermediários e básicos, que, seguindo-se a classificação de alguns autores que estudaram rochas semelhantes em outras regiões do mundo (Groves, 1935; Quensel, 1951; Cooray, 1962), constituem uma verdadeira "série charnockítica". Tanto o termo "série charnockítica" quanto o termo charnockito têm sido assunto de discussão nos diversos trabalhos versando sobre tais rochas. $O$ primeiro a utilizá-los foi Holand (1900), quando apresentou uma definição para ambos, restringindo o emprego do charnockito, sensu stricto, aos termos ácidos da série. Todavia, Subramaniam (1959), reestudando a região tipo de Madras, India, sugeriu que somente os membros ácidos deveriam ser agrupados em uma série charnockítica (charnockitos, enderbitos, hiperstênio-quartzo sienitos e alaskitos). Para os membros mais básicos, ele sugeriu a denominação de rochas híbridas. Apesar disso, o que se tem visto na literatura geológica é o livre emprego da denominação "série charnockítica", agrupando rochas ácidas, intermediárias e básicas, desde que ocorram relacionadas a charnockitos. Spooner (1969) prefere 
utilizar o termo "piroxênio granulito" para evitar o emprego indiscriminado da palavra "charnockito".

No presente trabalho, as rochas estão sendo denominadas genericamente de hiperstênio granulitos e subdivididas nos termos ácidos, intermediários e básicos da série charnockítica, com base no conteúdo de sílica. Os tipos básicos compõem-se essencialmente de plagioclásio, ortopiroxênio, clinopiroxênio e hornblenda; os intermediários de quartzo, pertita, plágioclásio e ortopiroxênio; e os ácidos de quartzo, pertita, plagioclásio e restos de ortopiroxênio. Como feição geral elas exibem tonalidades castanhas muito características quando intemperizadas e cinza esverdeada quando frescas, sendo essa cor devida muito mais à presença de feldspatos esverdeados do que a minerais ferromagnesianos.

Uma outra feição comum a essas rochas é a textura granoblástica sempre xenoblástica ou raramente hipidioblástica, aproximadamente equigranular, atingindo $5 \mathrm{~mm}$ em média nos tipos mais grosseiros e $0,5 \mathrm{~mm}$ nos mais finos. A estrutura pode ser granulosa ou, por vezes, gnáissica, com os minerais ferromagnesianos agrupados e orientados subparalelamente.

A composição mineralógica dos hiperstênios granulitos é apresentada na Tab. VI. Com base novamente na nomenclatura sugerida por Streckeisen (1967), verifica-se que os tipos básicos se aproximam de gabros e noritos, os intermediários de quartzo monzonitos, monzonitos e dioritos e, finalmente, os ácidos de granito.

Tabela VI - Análises modais de hiperstênio-granulitos

\begin{tabular}{|c|c|c|c|c|c|c|c|}
\hline & 180 & 111 & 34 & 176 & 201 & 205 & 190 \\
\hline Quartzo & - & 3,3 & 19,0 & 16,9 & 0,9 & 10,1 & 30,3 \\
\hline $\begin{array}{l}\text { Feldspato } \\
\text { potássico }\end{array}$ & - & 4,8 & 11,8 & 2,7 & 3,0 & 1,4 & 4,3 \\
\hline Pertita & - & 9,3 & 13,7 & 33,2 & 38,4 & 49,1 & 35,5 \\
\hline Plagioclásio & 38,9 & 39,6 & 28,0 & 26,1 & 39,7 & 28,2 & 22,6 \\
\hline Antipertita & - & 2,3 & 9,5 & 1,6 & 2,2 & 0,2 & - \\
\hline Mirmequita & - & - & 0,7 & 3,1 & 2,0 & 3,7 & 3,0 \\
\hline Ortopiroxênio & 15,8 & 13,0 & 2,7 & 6,9 & 6,0 & 2,2 & - \\
\hline Clinopiroxênio & 10,3 & 5,0 & 0,5 & 0,6 & 1,7 & 2,1 & - \\
\hline Hornblenda & 29,8 & 10,2 & 8,8 & 4,1 & 0,3 & 0,7 & 0,1 \\
\hline Biotita & 0,7 & 0,7 & 1,8 & 0,7 & 0,5 & 0,2 & 0,8 \\
\hline Apatita & 0,6 & 1,9 & 0,8 & 0,4 & 0,1 & - & $\mathrm{pr}$ \\
\hline Zircão & - & $\mathrm{pr}$ & $\mathrm{pr}$ & 0,1 & 0,1 & pr & 0,1 \\
\hline Opacos & 3,6 & 9,7 & 2,2 & 3,6 & 5,1 & 2,1 & 0,9 \\
\hline Clorita & 0,3 & - & - & - & - & - & 0,2 \\
\hline $\begin{array}{l}\text { Agregado } \\
\text { fibroso }\end{array}$ & - & 0,2 & 0,5 & - & - & - & 2,2 \\
\hline
\end{tabular}

Todo o feldspato potássico dessas rochas encontra-se na forma de pertita, à exceção de uma ou outra amostra em que microclínio, com ou sem intercrescimento, aparece em grãos interstiais como resultado de recristalizações. A pertita é muito fina (micropertita ou criptopertita), do tipo mesopertita capilar (hair perthite) ou em gotas elípticas, e seus cristais são ligeiramente maiores que os demais componentes, atingindo até $6 \mathrm{~mm}$ de comprimento. Exibem extinção ondulante e são sempre xenomórficos. Segundo Eskola (1952), a extinção ondulante é uma indicação do início de microclinização. O componente potássico das pertitas está mais próximo do microclínio que do ortoclásio, uma vez que as medidas de triclinicidade em duas amostras representativas (89-176) deram os 
valores 0,64 e 0,71. Estes, de conformidade com Goldsmith e Laves (1954), indicam triclinicidade média. As cores macroscópicas desse mineral variam de parda a verdemescura e parecem estar ligadas à existência de fraturas muito finas, preenchidas por material de coloração verde ou amarela (Oliveira, 1969).

Plagioclásio está presente em todas as variedades petrográficas, sendo o único constituinte siálico essencial dos tipos mais básicos. Nos tipos ácidos e intermediários, acha-se representado por um oligoclásio ou andesina sódica, com teores de anortita variando entre 20 e $32 \%$, enquanto que, nos tipos básicos, predomina uma andesina com teor de anortita entre 35 e $45 \%$. Apresenta-se sempre xenomórfico, límpido e quase sem geminação. Esta, aparecendo com mais freqüência nos tipos básicos, é do tipo albita ou periclínio.

Ortopiroxênio é o mineral ferromagnesiano característico desse grupo de rochas. Os termos encontrados são o hiperstênio, o ferro-hiperstênio e a eulita com valores da molécula de ferrossilita variando entre 40 e $80 \%$. Esses dados foram conseguidos a partir do diagrama de Hess (1952), utilizando-se medidas de índice de refração e 2V. Para os índices de refração foram obtidos valores de $N_{Z}$ entre 1,715 e 1,760 e de $N_{X}$ entre 1,700 e 1,742 e para o ângulo $2 V_{X}$ valores entre $53^{\circ}$ e $72^{\circ}$.

Os clinopiroxênios encontramuse representados pelos termos salita e ferrosalita da série diopsídio-hedenbergita, aparecendo um termo augítico junto às variedades mais básicas. Essas determinaçס̃es baseiam-se nas medidas de índices de refração, ângulo $2 \mathrm{~V}$ e ângulo de extinção $Z \Lambda c$, que apresentaram os seguintes valores médios $N_{Z}=1,720$, $N_{X}=1,690, Z \Lambda c=42^{\circ}$ e $2 V_{Z}=59^{\circ}$.

Outro componente ferromagnesiano dos hiperstênios granulitos é a hornblenda, que pode atingir nos tipos mais básicos até $30 \%$ da composição modal. Trata-se de hornblenda verde ou verde-parda, pleocróica, na forma de grãos hipidiomórficos ou, mais raramente, idiomórficos.

$\mathrm{Na} \mathrm{Tab.} \mathrm{VII} \mathrm{são} \mathrm{fornecidas} \mathrm{as} \mathrm{análises} \mathrm{químicas} \mathrm{de} \mathrm{sete} \mathrm{amostras} \mathrm{de} \mathrm{hiperstênio}$ granulitos, juntamente com a norma CIPW. Os valores apresentados mostram-se muito semelhantes aos obtidos em outras regióes do mundo para rochas dessa natureza e relacionadas nos trabalhos de Quensel (1951), Howie (1955 e 1965), Parras (1958)

ANFIBOLITOS E ROCHAS CALCIO-SILICÁTICAS Os anfibolitos são rochas de ocorrência restrita na área levantada. Compõem-se essencialmente de hornblenda verde, plagioclásio com teor médio de $\mathrm{An}_{40}$, biotita e clinopiroxênio.

A textura é granoblástica, aparecendo, às vezes, uma leve orientação subparalela das hornblendas e biotitas, quando pode ser chamada de nematoblástica. São rochas principalmente equigranulares com granulação média ao redor de $1 \mathrm{~mm}$.

Anfibolitos propriamente ditos e hiperstênio-anfibolitos constituem os tipos petrográficos principais. Análises modais e químicas de duas amostras constam da Tab. VIII.

As calcio-silicáticas, que ocorrem sob a forma de pequenos corpos lenticulares inseridos em meio aos gnaisses e granulitos, apresentam uma mineralogia variada em que se destacam clinopiroxênios (diopsidio), granada, escapolita, hornblenda parda, plagioclásio e forsterita.

Entre os componentes siálicos predomina o plagioclásio $\mathrm{An}_{30-40}$ em algumas amostras e a escapolita tipo mizzonita-meionita em outras.

O clinopiroxênio representa o principal constituinte ferromagnesiano dessas rochas. E aproximadamente equigranular, com diâmetro médio dos grãos entre 1 e $2 \mathrm{~mm}$, hipidiomórfico ou xenomórfico. As variedades presentes pertencem à série diopsídio-hedenbergita, com os termos diopsídio quase puro (amostra 6-A), salita e ferrosalita. Essas determinações foram obtidas a partir dos valores de índice de refração $\left(N_{Z}=1,697\right.$ a 1,750 e $N_{X}=1,668$ 
Tabela VII - Análises químicas e normas moleculares de hiperstênio granulitos de São José do Rio Pardo

\begin{tabular}{|c|c|c|c|c|c|c|c|c|c|c|c|c|c|c|c|c|c|c|c|c|}
\hline & & & & & & & & & & & & & & \multicolumn{7}{|c|}{ Normas moleculares } \\
\hline & 180 & 111 & 201 & 34 & 176 & 205 & 190 & A & B & $\mathrm{C}$ & D & $\mathrm{E}$ & & 180 & 111 & 201 & 34 & 176 & 205 & 190 \\
\hline $\mathrm{SiO}_{2}$ & 46,20 & 49,90 & 47,38 & 60,49 & 61,86 & 63,84 & 70,14 & 45,00 & 49,05 & 60,12 & 59,17 & 72,32 & $\mathrm{Qz}$ & - & - & 1,08 & 11,58 & 14,22 & 11,88 & 24,06 \\
\hline $\mathrm{TiO}_{2}$ & 1,50 & 1,18 & 0,14 & 0,85 & 1,20 & 0,80 & 0,65 & 2,40 & 2,01 & 0,95 & 0,99 & 0,16 & Or & 2,78 & 10,01 & 31,69 & 14,46 & 21,13 & 30,02 & 33,92 \\
\hline $\mathrm{Al}_{2} \mathrm{O}_{3}$ & 16,20 & 12,46 & 17,33 & 15,10 & 15,70 & 15,14 & 15,00 & 16,62 & 12,82 & 16,63 & 15,53 & 14,46 & $\mathrm{Ab}$ & 27,25 & 37,20 & 34,06 & 37,73 & 30,92 & 37,73 & 27,25 \\
\hline $\mathrm{Fe}_{2} \mathrm{O}_{3}$ & 6,94 & 8,48 & 3,75 & 3,88 & 2,33 & 3,02 & 0,37 & 6,05 & 2,76 & 2,19 & 2,03 & 1,24 & An & 28,36 & 9,17 & 13,34 & 13,90 & 15,85 & 6,12 & 7,78 \\
\hline $\mathrm{FeO}$ & 9,17 & 10,05 & 5,59 & 3,98 & 4,49 & 3,26 & 1,80 & 8,97 & 14,50 & 4,79 & 5,40 & 0,67 & Di & 8,53 & 18,86 & 3,29 & 10,79 & 6,04 & 6,26 & - \\
\hline $\mathrm{MnO}$ & 0,19 & 0,21 & 0,20 & 0,09 & 0,18 & 0,11 & 0,05 & 0,31 & 0,35 & 0,10 & 0,06 & 0,02 & Hy & 9,37 & 6,60 & 9,74 & 3,36 & 5,30 & 1,33 & 3,91 \\
\hline $\mathrm{MgO}$ & 7,20 & 3,50 & 1,60 & 2,34 & 1,50 & 0,87 & 0,67 & 7,24 & 4,55 & 0,82 & 2,94 & 0,33 & $\mathrm{Ol}$ & 9,77 & 1,86 & - & - & - & - & - \\
\hline $\mathrm{CaO}$ & 8,04 & 7,12 & 3,63 & 5,66 & 4,82 & 2,89 & 1,56 & 9,50 & 10,06 & 3,75 & 5,68 & 1,78 & Ap & 0,34 & 1,34 & 0,34 & 0,34 & 0,34 & 0,34 & - \\
\hline $\mathrm{Na}_{2} \mathrm{O}$ & 3,20 & 4,40 & 4,05 & 4,50 & 3,65 & 4,45 & 3,24 & 2,76 & 3,12 & 4,73 & 4,22 & 3,39 & Il & 2,89 & 2,28 & 0,30 & 1,67 & 2,28 & 1,52 & 1,22 \\
\hline $\mathrm{K}_{2} \mathrm{O}$ & 0,52 & 1,70 & 5,40 & 2,42 & 3,60 & 5,05 & 5,75 & 0,96 & 0,91 & 4,25 & 3,19 & 4,92 & Mt & 9,98 & 12,30 & 5,34 & 5,57 & 3,25 & 4,41 & 0,46 \\
\hline $\mathrm{H}_{2} \mathrm{O}^{+}$ & 0,60 & 0,14 & 0,45 & 0,42 & 0,35 & 0,38 & 0,47 & 0,16 & - & 0,25 & 0,11 & 0,50 & $\mathrm{C}$ & - & - & - & - & - & - & 0,61 \\
\hline $\mathrm{H}_{2}^{-} \mathrm{O}^{-}$ & 0,03 & 0,20 & 0,11 & 0,20 & 0,05 & 0,02 & 0,20 & 0,06 & 0,09 & - & 0,14 & 0,34 & & & & & & & & \\
\hline $\mathrm{P}_{2} \mathrm{O}_{5}$ & 0,18 & 0,57 & 0,11 & 0,21 & 0,15 & 0,12 & 0,00 & - & 0,36 & 0,77 & 0,47 & - & & & & & & & & \\
\hline Total & 99,98 & 99,91 & 99,74 & 100,14 & 99,88 & 99,95 & 99,90 & 100,03 & 100,58 & 99,56 & 99,93 & 100,13 & & & & & & & & \\
\hline $\begin{array}{l}\text { Peso } \\
\text { específico }\end{array}$ & 3,06 & 2,99 & 2,78 & 2,77 & 2,79 & 2,70 & 2,65 & 3,19 & 3,12 & 2,77 & 2,80 & 2,67 & & & & & & & & \\
\hline
\end{tabular}

$\mathrm{A}=$ Charnockito básico, Varberg-Suécia (Quense), 1951)

$\mathrm{B}=$ Homblenda-norito, Madras-Îndia (Howie, 1955)

180 = Hiperstênio-granulito básico. São José do Rio Pardo

$\mathrm{C}=$ Charnockito intermediário, Varberg-Suécia (Quensel, 1951)

$\mathrm{D}=$ Rocha intermediária, Madras-Índia (Howie, 1955)

11 = Hiperstênio-granulito básico. São José do Rio Pardo

201 = Hiperstênio-granulito intermediário. São José do Rio Pardo

34 = Hiperstênio-granulito intermediário. São José do Rio Pardo

$\mathrm{E}=$ Charnockito félsico, Varberg-Suécia (Quensel, 1951)

= Hiperstênio-granulito intermediario. São José do Rio Pardo

$190=$ Hiperstênio-granulito ácido. São José do Rio Pardo 
Tabela VIII - Análises modais, análises químicas e normas moleculares de anfibolitos

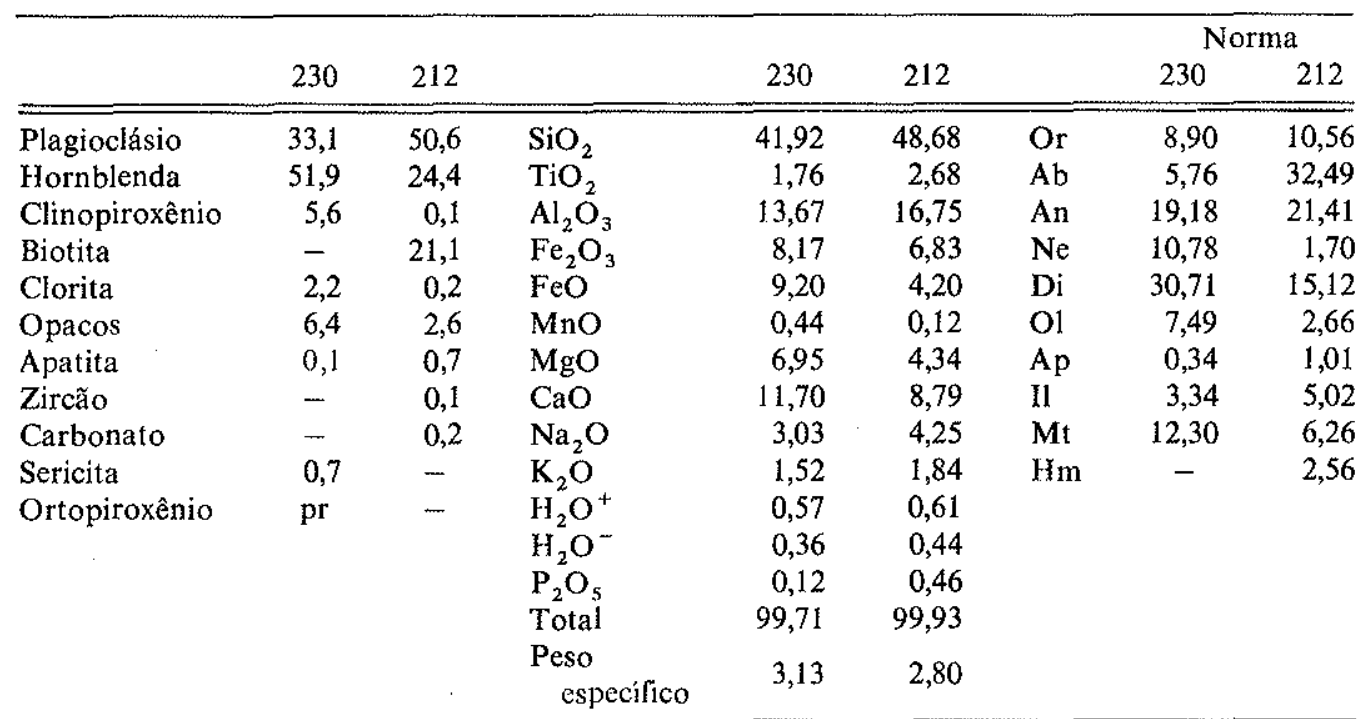

Analista: Raphael Hypólito, DMP-IG

a 1,720), ângulo $2 V_{Z}\left(56^{\circ}\right.$ a $\left.61^{\circ}\right)$ e peso específico $(3,29$ a 3,52$)$. Os termos mais próximos do diopsídio são verdes muito claros ou incolores e os demais termos são levemente pleocróicos.

A granada apresenta-se em grãos arredondados, com diâmetro inferior a $0,5 \mathrm{~mm}$, inclusos nos piroxênios, agrupados ou alinhados, conferindo certa orientação à rocha. Exibe cores amarelo-avermelhadas ou castanho-avermelhadas. A determinação das propriedades físicas de uma das amostras $\left(n=1,800 ; D=3,726\right.$ e $\left.a_{0}=11,92 \AA\right)$ revelou tratar-se de uma mistura das "moléculas" grossulária e andradita, com pequenas porcentagens de almandina, segundo os diagramas de Sriramadas (1957). Entre os tipos petrográficos estudados registraram-se piroxenitos puros (diopsiditos), granada-piroxenitos, escapolita-piroxenitos, mármores com diopsídio (às vezes wollastonita e forsterita), anfibolitos e piroxênio granulitos cálcicos associados.

Petrogênese EVIDÊNCIAS DE CAMPO As informações constantes dos capítulos anteriores mostram que, na região de São José do Rio Pardo, rochas granulíticas ocorrem associadas a gnaisses e migmatitos e que o processo de migmatização afetou tanto os granulitos como os gnaisses, sendo, portanto, um evento posterior à formação dessas rochas, uma vez que gnaisses e granulitos constituem em toda área o paleossoma dos migmatitos.

Os dados de campo parecem indicativos de uma origem sedimentar para muitos gnaisses. Entre eles, cite-se a ocorrência, em alguns pontos da área, de bancos quartzíticos ou de gnaisses extremamente ricos em quartzo, assim como a presença de corpos de granada gnaisses distribuídos por toda a região e em contatos transicionais com os demais tipos que, provavelmente, resultaram do metamorfismo de sedimentos argilosos.

Para os granulitos, as relaçôes de campo não são muito esclarecedoras. Corpos com formas irregulares tendendo a lenticulares, concordantes com a orientação regional, de contatos transicionais, depois de afetados por metamorfismo de grau elevado, podem sugerir uma origem tanto a partir de sedimentos como de rochas intrusivas. Somente os hiperstênio-granulitos básicos e hiperstênio anfibolitos, ocorrendo na forma de pequenos 
corpos de contatos mais ou menos definidos, parecem representar antigas intrusões de rochas básicas.

Para as rochas calcio-silicáticas, entretanto, pode-se admitir, com relativa certeza, uma origem metassedimentar a partir de antigas lentes de calcários impuros, uma vez que mármores com diopsídio e forsterita são encontrados em íntima associação com os piroxenitos e granada piroxenitos.

EVIDÊNGIAS PETROGRÁFICAS Embora a litologia global de São José do Rio Pardo exiba diversas associações de minerais em fácies metamórficas um pouco diferentes, existem feiçôes mineralógicas comuns a todos os tipos petrográficos, indicativas de que o conjunto foi submetido às mesmas condições de metamorfismo. Entre essas feições, enumeram-se as seguintes:

1) presença em todas as variedades petrográficas de pertitas muito finas do tipo mesopertita;

2) da mesma forma, a antipertita está presente em pequenas quantidades nos gnaisses, migmatitos e granulitos;

3) plagioclásio, representado por uma andesina sódica, é o mineral essencial de praticamente todas as rochas estudadas. Chama particularmente a atenção o seu baixo teor em anortita, constante para toda área, bem como seu aspecto límpido, quase sem geminação;

4) clinopiroxênio (salita e ferrosalita) como principal constituinte ferromagnesiano dos gnaisses, migmatitos e granulitos;

5) a textura granoblástica típica para as rochas regionais.

Por outro lado, podemos, da mesma forma, enumerar diversas outras feições mineralógicas e petrográficas resultantes de um evento metamórfico posterior à fase principal. São elas :

1) deformaçőes generalizadas, provocando a orientação (grãos de quartzo e pertita alongados e orientados), fraturamentos e redução da granulação de minerais;

2) recristalização de alguns minerais, principalmente microclínio nos interstícios e nas bordas das pertitas, ou como porfiroblastos em gnaisses;

3) alteração de diversos constituintes, caracterizada pelo aparecimento de formas hidratadas. Esse é o caso dos piroxênios, freqüentemente alterados em hornblenda verde ou material clorítico.

$\mathrm{O}$ estudo petrográfico revelou também que as paragêneses minerais que seguem.

Gnaisses: quartzo-andesina-antipertita-clinopiroxênio (biotita); quartzo-microclínio-pertita-oligoclásio-biotita e/ou hornblenda. rita).

Kinzigitos: quartzomortoclásio-andesina-biotita-granada (antipertita-sillimanita-cordie-

Granulitos: quartzo-mesopertita-oligoclásio; andesina-ortopiroxênio-clinopiroxênio-hornblenda; mesopertita-oligoclásio-ortopiroxênio-clinopiroxênio.

Anfibolitos: andesina-hornblenda (biotita)

Calcio-silicáticas: andesina-clinopiroxênio-hornblenda (granada); escapolita-clinopiroxênio-granada. 
O simples exame dessas paragêneses revela a coexistência de duas fácies metamórficas: a fácies anfibolito e a fácies granulito de Fyfe e Turner (1966) e Turner (1968). De acordo com o último autor, as associações de minerais dos kinzigitos correspondem a composições pelíticas, as associações do grupo granulitos são charnockíticas, e as associações calcio-silicáticas são calcárias, todas compatíveis com as condições da fácies granulito. As associações típicas da fácies anfibolito são poucas, sendo grande parte delas transicionais para a fácies granulito.

EVIDENGIAS QUIMICAS Foram executadas diversas análises químicas de rochas de São José do Rio Pardo, dando-se especial atenção aos tipos charnockíticos. Essas análises constam das Tabs. II, IV, V, VII e VIII.

Embora sem conhecer até que ponto a diferenciação metamórfica afetou a composição química dessas rochas, o exame das análises permite tirar algumas conclusões interessantes.

Os caracteres químicos do kinzigito, por exemplo, são muito semelhantes aos do folhelho, o que favorece a conclusão de ser a primeira rocha originada de sedimentos argilosos. A principal diferença consiste no enriquecimento em $\mathrm{MgO}, \mathrm{FeO}$ e $\mathrm{Fe}_{2} \mathrm{O}_{3}$ com relação aos folhelhos. Mehnert (1968) explica a origem dos kinzigitos, em áreas migmatizadas, como "restritos" enriquecidos em $\mathrm{Mg}, \mathrm{Al}$ e $\mathrm{Fe}$ (correspondendo à paragênese biotita-sillimanita-cordierita-granada-espinélio), representando porções não-mobilizadas. Essa hipótese poderia explicar o enriquecimento daqueles elementos nas rochas de São José do Rio Pardo, em muitos locais nitidamente afetadas pela migmatização.

Quanto aos tipos básicos, pode-se observar que a composição dos hiperstênio granulitos é muito semelhante à dos anfibolitos e à média dos gabros fornecida por Nockolds (1954). Para os granulitos, as evidências de campo favorecem realmente uma origem magmática. Para os anfibolitos, todavia, existe um ponto a considerar: como melanossoma dos migmatitos, até que ponto essas rochas poderiam ser consideradas produtos da migmatização? As análises químicas dos anfibolitos revelam um enriquecimento em ferro e álcalis, relativamente às rochas ígneas básicas, que poderia ser explicado pela migmatização.

Para as rochas charnockíticas intermediárias, vê-se que a composição dos quatro hiperstênio-granulitos é muito semelhante à média dos quatro gnaisses a Tab. II, sendo as diferenças mais significativas referentes aos elementos $\mathrm{Ca}, \mathrm{Mg}$ e Fe. Essas análíses, por sua vez, mostram pequenas diferenças quando comparadas à média das rochas igneas e à média dos folhelhos. Esse fato torna dificil fazer-se qualquer especulação sobre a sua gênese, que tanto poderia ser ígnea como sedimentar.

Finalmente, é possível, ainda, compararuse os granulitos alaskíticos e os hiperstênio granulitos ácidos com a média dos granitos apresentada por Nockolds (1954). Conclui-se que existe uma grande semelhança química entre esses tipos de rocha, admitindo-se assim, para os granulitos alaskíticos com ou sem hiperstênio, uma origem a partir de material granítico, que poderia ser resultante seja de intrusð̌es graníticas, seja da anatéxis parcial de rochas preexistentes.

Usando-se o mesmo procedimento seguido por Howie (1955) e Singh (1966), foram elaborados diagramas de variação química com a finalidade de verificar se as rochas charnockíticas poderiam representar frações diferenciadas de magma, conclusão a que chegaram os citados autores, estudando respectivamente rochas da India e da República da Guiana. Para tanto, as análises químicas foram recalculadas em porcentagens catiônicas, cujos resultados constam da Tab. IX, juntamento com o índice de Larsen modificado por Nockolds e Allen (1953) $(1 / 3 \mathrm{Si}+\mathrm{K})-(\mathrm{Ca}+\mathrm{Mg})$ e as relaçoes $\mathrm{K}: \mathrm{Na}: \mathrm{Ca}$ e $\left(\mathrm{Fe}^{2+}+\right.$ $\left.+\mathrm{Fe}^{3+}\right):(\mathrm{Na}+\mathrm{K}): \mathrm{Mg}$. Os diagramas de variação estão representados nas Figs. 4 e 5. 
Tabela IX - Análises químicas, em porcentagem catiónica, das rochas charnockíticas de São José do Rio Pardo

\begin{tabular}{crrrrrrr}
\hline & 180 & 111 & \multicolumn{1}{c}{201} & \multicolumn{1}{c}{34} & 176 & 205 & 190 \\
\hline \hline $\mathrm{Si}^{4+}$ & 21,56 & 23,28 & 26,47 & 28,22 & 28,86 & 29,79 & 32,73 \\
$\mathrm{Ti}^{4+}$ & 0,90 & 0,71 & 0,08 & 0,51 & 0,72 & 0,48 & 0,39 \\
$\mathrm{Al}^{3+}$ & 8,58 & 6,60 & 9,17 & 7,99 & 8,31 & 8,01 & 7,94 \\
$\mathrm{Fe}^{3+}$ & 4,86 & 5,93 & 2,63 & 2,72 & 1,63 & 2,11 & 0,26 \\
$\mathrm{Fe}^{2+}$ & 7,13 & 7,81 & 4,35 & 3,10 & 3,49 & 2,53 & 1,40 \\
$\mathrm{Mg}^{2+}$ & 4,32 & 2,10 & 0,96 & 1,40 & 0,90 & 0,52 & 0,40 \\
$\mathrm{Ca}^{2+}$ & 5,74 & 5,08 & 2,59 & 4,04 & 3,44 & 2,06 & 1,11 \\
$\mathrm{Na}^{+}$ & 2,37 & 3,26 & 3,00 & 3,34 & 2,71 & 3,30 & 2,40 \\
$\mathrm{~K}^{+}$ & 0,43 & 1,41 & 4,48 & 2,01 & 2,99 & 4,19 & 4,77 \\
$\mathrm{~K}$ & 5,0 & 14,5 & 44,5 & 21,4 & 32,7 & 43,9 & 57,6 \\
$\mathrm{Na}$ & 27,7 & 33,4 & 29,8 & 35,6 & 29,6 & 34,5 & 29,0 \\
$\mathrm{Ca}$ & 67,2 & 52,1 & 25,7 & 43,0 & 37,6 & 21,6 & 13,4 \\
$\mathrm{Fe}$ & 62,7 & 67,0 & 45,3 & 46,3 & 43,7 & 36,7 & 18,0 \\
$\mathrm{Alk}$ & 14,6 & 22,8 & 48,5 & 42,6 & 48,6 & 59,2 & 77,7 \\
$\mathrm{Mg}$ & 22,6 & 10,2 & 6,2 & 11,1 & 7,7 & 4,1 & 4,3 \\
$(1 / 3 \mathrm{Si}+\mathrm{K})-(\mathrm{Ca}+\mathrm{Mg})$ & $-2,4$ & $+2,0$ & $+9,8$ & $+6,0$ & $+8,3$ & $+11,5$ & $+14,2$ \\
\hline
\end{tabular}

Na Fig. 4, observa-se a existência de uma variação contínua e regular dos diversos elementos projetados desde a posição -3 até a posição +15 . Deve-se ressaltar que o comportamento das curvas é idêntico àquele apresentado no diagrama de Howie (1955, p. 735) e por Singh (1966, p. 188).

No diagrama triangular da Fig. 5, acham-se projetadas as relaçðes $\mathrm{K}: \mathrm{Na}: \mathrm{Ca}$ e $\left(\mathrm{Fe}^{2+}+\mathrm{Fe}^{3+}\right):(\mathrm{Na}+\mathrm{K}): \mathrm{Mg}$. Observa-se que, para ambos os casos, as curvas indicam comportamentos nítidos: na primeira, para quantidades mais ou menos constantes de $\mathrm{Na}$, há enriquecimento progressivo de $\mathrm{K}$ relativamente a $\mathrm{Ca}$; para a segunda, com quantidades aproximadamente iguais de $\mathrm{Mg}$, há enriquecimento em $\mathrm{Fe}$ total com diminuição dos álcalis $(\mathrm{Na}+\mathrm{K})$. Da mesma forma, essas curvas são semelhantes às obtidas por Howie (1955, p. 736) e perfeitamente comparáveis às encontradas junto a uma série de rochas ígneas álcali-cálcicas. Com base nessas informaçzes, Howie (1955) admitiu para a série charnockíticas de Madras uma origem a partir de rochas ígneas plutônicas, submetidas posteriormente à recristalização sob condições de metamorfismo plutônico. Segundo esse autor, dificilmente rochas sedimentares forneceriam curvas tão definidas como as apresentadas em seu trabalho.

Para as rochas charnockíticas de São José do Rio Pardo, em vista da semelhança mostrada com a série charnockítica de Madras, poder-se-ia também admitir que o material original, submetido a metamorfismo de fácies granulito, constituiu, no conjunto, uma série de rochas calco-alcalinas diferenciadas.

Além desses diagramas, foi elaborado também um outro (Fig. 6), utilizando-se os valores normativos $\mathrm{Q} A \mathrm{Ab}$ e Or das rochas de São José do Rio Pardo e as informações contidas em Winkler (1965). Verificou-se que dos pontos projetados apenas as amostras $188,30,190$ e 83 situam-se dentro do campo de maior frequiência de 1190 rochas graniticas obtido por Winkler e V. Platen (1961). Esse campo confunde-se com aquele resultante da projeção das razões $\mathrm{Q}: \mathrm{Ab}:$ Or de pontos eutéticos de fusões anatexíticas. Com base nesses resultados, poder-se-ia dizer que tais rochas, à exceção da amostra 83 , poderiam ter-se cristalizado a partir de líquidos anatexíticos resultantes da palingênese de rochas mais antigas. 


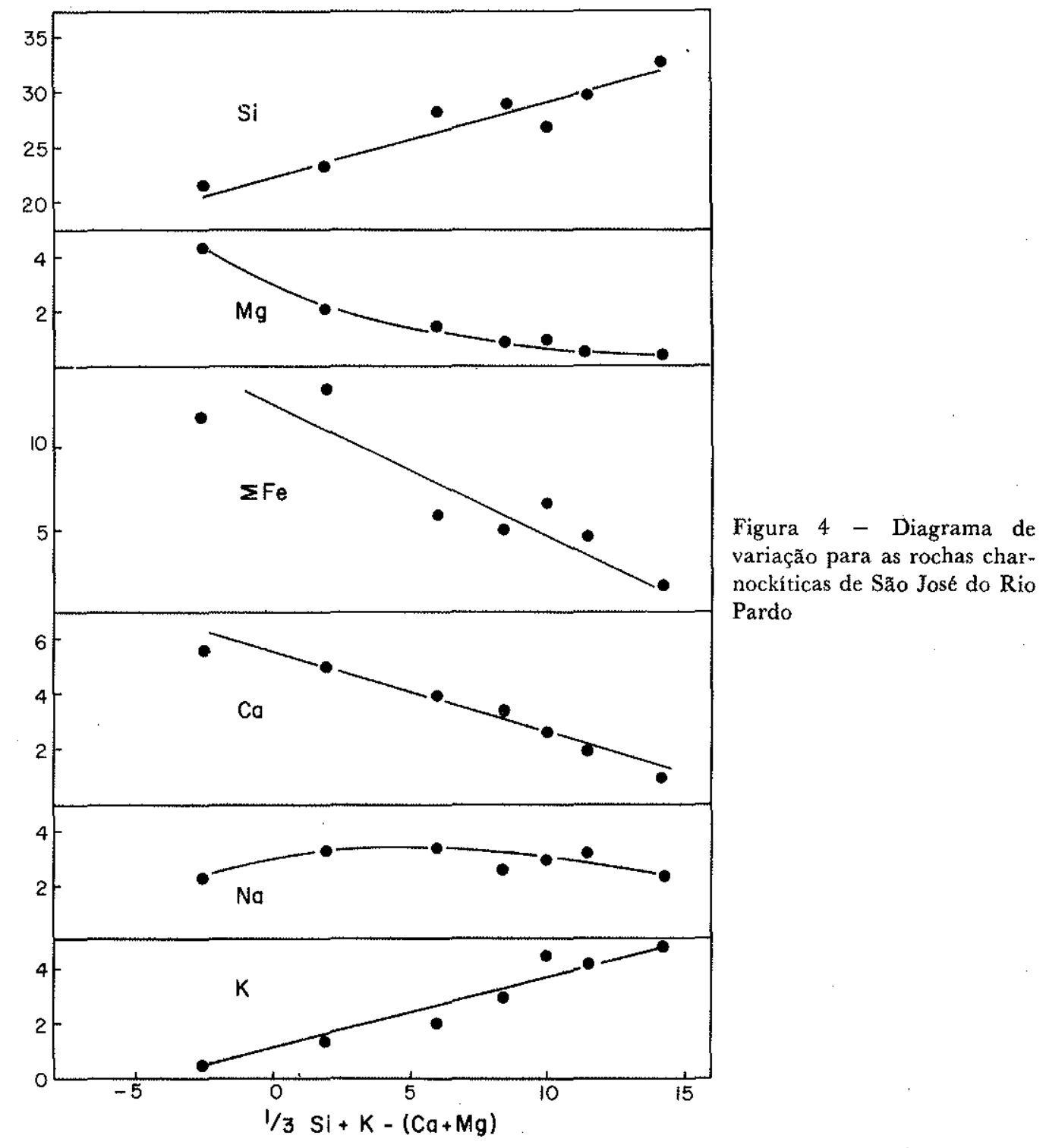

DADOS GEOCRONOLÓGICOS Cinco amostras da área de São José do Rio Pardo foram objeto de datação geocronológica, sendo quatro no Centro de Pesquisas Geocronológicas da Universidade de São Paulo, pelo método potássio-argônio (K/Ar) em anfibólios, e uma no Centre Belge de Géochronologie, pelo método rubídio-estrôncio $(\mathrm{Rb} / \mathrm{Sr}) \mathrm{em}$ rocha total.

Três resultados K/Ar provêm de anfibolitos, sendo que dois deles (6 e 70) acham-se associados às calco-silicáticas do extremo nordeste da área, enquanto que a terceira ocorrência (137) corresponde à faixa anfibolítica de rocha migmatítica com leucossoma granítico aflorando na parte sul. A amostra restante (24) representa um pequeno corpo de hiperstênio-granulito básico e localiza-se na parte central da área. A idade $\mathrm{Rb} / \mathrm{Sr}$ foi obtida em granulito róseo, alaskítico, amostra 53. Os resultados, integrando a Tab. IX, 
Figura 5 - Diagrama de variação para as rochas charnockíticas de São José do Rio Pardo
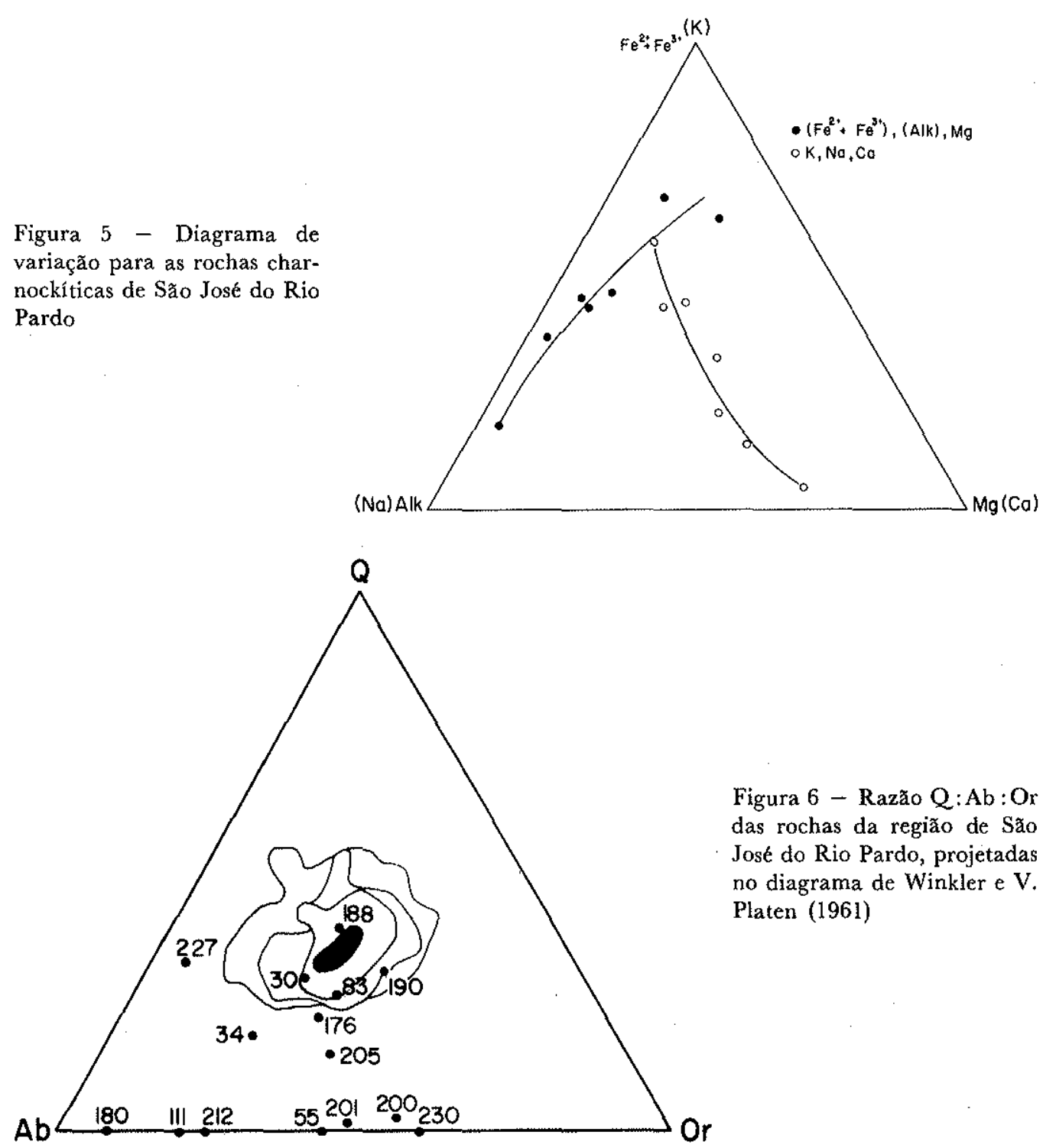

Figura 6 - Razão Q:Ab:Or das rochas da região de São José do Rio Pardo, projetadas no diagrama de Winkler e V. Platen (1961)

Tabela X - Determinaçðes geocronológicas

\begin{tabular}{lccccc}
\hline \multicolumn{1}{c}{ Rocha } & N. $^{\circ}$ do campo & N. $^{\circ}$ do exemplar & Método & Material & Idade (m.a.) \\
\hline \hline Anfibolito & 6 & SPK-1 817 & $\mathrm{K}^{40} / \mathrm{Ar}^{40}$ & Anfibólio & $666 \pm 26$ \\
$\begin{array}{l}\text { Anfibolito } \\
\text { Anfibolito }\end{array}$ & 70 & SPK-1 818 & Idem & Idem & $617 \pm 8$ \\
$\begin{array}{l}\text { Hiperstênio- } \\
\text {-granulito }\end{array}$ & 137 & SPK-2 067 & Idem & Idem & $677 \pm 32$ \\
$\begin{array}{l}\text { Granulito } \\
\text { róseo }\end{array}$ & 24 & SPK-2 392 & Idem & Idem & $598 \pm 10$ \\
\hline
\end{tabular}

$* \lambda=1,47 \cdot 10^{-11} \operatorname{anos}^{-1}$ e $\left(\mathrm{Sr}^{87} / \mathrm{Sr}^{86}\right)_{o}$ assumido $=0,708 \pm 0,004$ 
quando analisados em conjunto com as observações geológicas e petrográficas permitem deduzir que a idade aproximada de $600 \mathrm{~m}$.a. corresponde à fase de intensa migmatização que afetou a região, provocando fenômenos de metassomatismo, deformaçð̃es e recristalizaç̃̃es em rochas preexistentes (hiperstênio-granulitos, por exemplo).

Os valores $\mathrm{K} / \mathrm{Ar}$ de 666 a $677 \mathrm{~m} . \mathrm{a}$. em anfibólio sugerem a existência de um evento geológico mais antigo, sem dávida ligado à formação dos granulitos, enquanto que a idade $\mathrm{Rb} / \mathrm{Sr}$ de $620 \pm$ m.a., para o granulito alaskítico, mostra que o intenso metassomatismo potássico provocou elevação do teor de $\mathrm{Rb}$ e conseqüente aumento da razão $\mathrm{Rb} / \mathrm{Sr}$ nessas rochas.

A idade radiométrica média de 600 m.a. marca a fase de formação do cinturão orogenético Paraíba, tal como definiram Cordani et. al. (1968) e, posteriormente, denominado Ribeira, segundo Cordani (1971). Pode-se depreender do mapa apresentado por esses autores, que a área de São José do Rio Pardo corresponde à regiåo de convergência do cinturão orogenético Ribeira com o cinturão orogenético Brasília.

CONDIÇÕES DE METAMORFISMO Os dados coligidos são indicativos de que as rochas da região de São José do Rio Pardo foram submetidas a duas fases de metamorfismo superpostas: a primeira, predominante, produzindo associaçð̃es características da fácies granulito, e a segunda responsável pela formação de paragênese da fácies anfibolito.

As condições de metamorfismo da fácies granulito ainda não estão bem definidas, existindo muitos aspectos passíveis de discussão. A grosso modo, pode-se dizer que ela é indicativa de altas pressões e temperaturas. A ausência em algumas paragênese de minerais hidratados é feição sugestiva de cristalização em ambiente com baixa pressão de água ou de que temperaturas muito elevadas impediram a cristalização de fases hidratadas. Todavia a presença de biotita gnaisses graníticos, anfibolitos ou granulitos alaskíticos associados às rochas charnockíticas, as menos hidratadas, parece indicar que as rochas da região de São José do Rio Pardo não tenham sido completamente anidras através do tempo e do espaço. Considerando-se que as condiçóes de fácies granulito confundem-se com o campo das fusões parciais e que a temperatura de fusão de materiais de composição granítica é fortemente dependente da pressão parcial de água, é normal encontrar-se rochas graníticas associadas a granulitos.

Para a temperatura de formação dessas rochas, admitem-se valores muito elevados $\left(660^{\circ}\right.$ a $\left.715^{\circ}\right)$, como evidenciado pela presença das mesopertitas e antipertitas (dados obtidos em Mehnert, 1968).

Adotando-se a classificação de Lambert e Heier (1968), poder-se-ia tomar os granulitos da região estudada como sendo de pressão média. Essa classificação associa a pressão de formação com a composição química das rochas da fácies granulito, pressupondo a existência de uma certa diferenciação metamórfica. Agrupa ainda as rochas em ácidas, subácidas, intermediárias e básicas, com base na quantidade de sílica presente. A predominância de tipos ácidos corresponde a condições de baixa pressão, enquanto que a maior abundância de tipos intermediários e básicos é indicativa de pressões médias a elevadas. Como na área de São José do Rio Pardo os tipos intermediários são mais freqüentes, ter-se-iam assim pressões de formação de média intensidade.

Lambert e Heier (1968), estudando rochas granulíticas do Escudo Australiano, admitiram que o metamorfismo da fácies granulito tenha acarretado certa modificaçðes na sua composição original, bem como conclúram que fusões parciais são os principais fatores responsáveis pela diferenciação. À conclusão semelhante chegou Sighinolfi (1971), investigando terrenos metamórficos de fácies granulito da Bahia. Segundo esse último autor, os granulitos de composição química intermediária correspondem a resíduos pro- 
cessos de fusões parciais, sendo esses processos responsáveis pelo aparecimento de trends magmáticos nos resíduos (granulitos) e pelo fracionamento de certos elementos.

Hipótese semelhante é aplicável à região de São José do Rio Pardo, em vista da existência de porções graníticas e trends magmáticos associados aos hiperstênio-granulitos. Anatéxis parcial das rochas inicialmente submetidas ao metamorfismo, produzindo líquidos graníticos e resíduos diferenciados, parece ser uma origem bastante plausivel para essas rochas.

CONSIDERAÇÕES FINAIS A gênese das rochas metamórficas de São José do Rio Pardo pode ser resumida pelos eventos que seguem.

a. Formação de uma seqüência de rochas sedimentares, predominando folhelhos e grauvaques, com arcósios, arenitos e calcários subordinados. Intrusão de rochas ígneas básicas e possivelmente calco-alcalinas.

b. Metamorfismo crescente em fase de orogênese, originando inicialmente gnaisses, quartzitos, mármores, piroxenitos e anfibolitos. Quando atingidas as condições da fácies granulito, em circunstâncias favoráveis, deve ter ocorrido anatéxis parcial, sugerida pela existência de rochas de composição granítica (granulitos e gnaisses graníticos) intercaladas com todos os tipos, principalmente charnockitos, e pela presença de litologias com associaçães anidras, como piroxênio granulitos e gnaisses granodioríticos.

c. Formação dos migmatitos, evento caracterizado pela idade de 600 m.a., e marcado por deformações e recristalizaçסes generalizadas nas rochas regionais, bem como pela presença de intenso metassomatismo potássico. Nessa fase os granulitos adquiriram textura granoblástica cataclástica, com os grãos de quartzo alongados e demais elementos deformados e orientados. Reações retrometamórficas, como a transformação dos piroxênios em hornblenda, ocorreram também durante esse evento.

d. Falhamentos regionais cretácicos e terciários cortaram a área na direção principal $\mathrm{NE}$, originando localmente milonitos. Por fim, a região foi elevada, propiciando a expon sição desse terreno metamórfico profundo.

Agradecimentos $\mathrm{O}$ autor deseja expressar seu agradecimento ao Conselho Nacional de Pesquisas pelo auxílio financeiro concedido para trabalhos de campo e de laboratório, bem como ao professor José Moacyr Vianna Coutinho pela orientação e colaboração dispensadas durante as diversas fases de preparação deste trabalho.

\section{BIBLIOGRAFIA}

COORAY, P. G. - 1962 - Charnockites and their associated gneisses in the Precambrian of Ceylon. Quart. Jour. Geol. Soc., London, 118: 239

CORDANI, U. G. - 1971 - Síntese da Geocronologia Pré-Cambriana da Região Costeira Atlântica Meridional da América do Sul. XXV Congresso Brasileiro de Geologia. Resumo das Comunicações, p. 179

CORDANI, U. G., MELGHER, G. C. e ALMEIDA, F. F. M. de - 1968 - Outline of the Precambrian geochronology of South America Can. Journ. of Earth Sciences, 5: 629

EBERT, H. - 1968 - Ocorrência da fácies granulítica no sul de Minas Gerais e em áreas adjacentes, em dependência da estrutura orogêntica: hipótese sobre sua origem. An. Acad. Bras. Cienc., 40 (suplemento): 215

ESKOLA, P. - 1952 - On the granulites of Lapland. Am. Journ. Sci. Bowen Volume, p. 137 FYFE, W.S. e TURNER, F. J. - 1966 - Reappraisal of the metamorphic facies concept. Contr. Miner. Petrol., 12: 354 
GOLDSMITH, J. R. e LAVES, F. - 1954 - The microcline-sanidine stability reactions. Geochim. et Cosmoch. Acta, 5: 1

GROVES, A. W. - 1935 - The charnockite series of Uganda, British East Africa. Quart. Journ. Soc., London, 91 : 150

HESS, H. H. - 1949 - Chemical composition and properties of common clinopyroxenes. Amer. Mineral., 34: 621

HESS, H.H. - 1952 - Orthopyroxenes of the Bushvel type, ion substitution and changes in unit cell dimensions. Am. Jour. Sci. Bowen Volume, p. 173

HOWIE, R. A. - 1955 - The geochemistry of the charnockite series of Madras, India. Royal Soc. Edinburgh Trans., 62: 725

HOWIE, R. A. - 1964 - Charnockites. Sci. Progress, 52: 622

HOWIE, R.A. - 1965 - The geochemistry and mineralogy of some charnockites from Baffin Island, Brazil, British Guiana, Congo, Madras and Uganda. Indian Miner., 6: 67

HOLLAND, T. H. - 1900 - The charnockite series, a group of hypersthenic rocks in peninsular India. Mem. Geol. Surv. Ind., V. 28

LAMBERT, I. B. e HEIER, K. S. - 1968 - Geochemical investigations of deep-seated rocks in the Australian Shield. Lithos, 1: 30

MEHNERT, K. R. - 1968 - Migmatites and the origin of granitic rocks. Elsevier Publishing Company, Amsterdam

NOCKOLDS, S. R. - 1954 - Average chemical composition of some igneous rocks. Bull. Geol. Soc. Amer., 65: 1007

NOCKOLDS, S. R. e ALLEN, R.S. - 1953 - The geochemistry of some igneous rock series. Geochim. et Cosmoch. Acta, 4: 105

OLIVEIRA, M. A.F. de - 1969 - Rochas charnockíticas da região de São José do Rio Pardo, São Paulo. Departamento de Mineralogia e Petrologia do Instituto de Geociências (mimeografado)

PARRAS, K. - 1958 - On the charnockites in the light of highly metamorphic rock complex in Southwestern Finland. Bull. Comm. Geol. Finlande, $181: 1$

QUENSEL, P. - 1951 - The charnockite series of the Varberg district on the south-western coast of Sweden. Arkiv for mineralogie och geologi, 1: 227

SIGHINOLFI, G.P. - 1971 - Investigations into deep crustal levels: fractionating effects and geochemical trends related to high-grade metamorphism. Geochim. et Gosmoch. Acta, 35: 1005

SIMONEN, A. - 1953 - Stratigraphy and sedimentation of Svecofennidic, early Archean supracrustal rocks in Southwestern. Finland. Bull. Comm. Géol. Finlande, 160: 1

SINGH, S. - 1966 - Orthopyroxene-bearing rocks of charnockitic affinities in the South Savanna Kanuku Complex of British Guiana. J. Petrol., 7: 171

SPOONER, C. M. $-1969-\mathrm{Sr}^{87} / \mathrm{Sr}^{86}$ initial ratios and whole rock ages of pyroxene granulite. M. I. T., Fifteenth Annual Progress Report, p. 45

SRIRAMADAS, A. - 1957 - Diagrams for the correlation of unit cell adges and refractive indices with the chemical composition of garnets. Amer. Mineral., 42: 294

STRECKEISEN, A. L. - 1967 - Classification and nomenclature of igneous rocks. N. Jb. Miner. Abh., 107: 144

SUBRAMANIAM, A. P. - 1959 - Charnockites of the type area near Madras; a reinterpretation. Am. Jour. Sci., 257: 321

TURNER, F. J. - 1968 - Metamorphic petrology; mineralogical and field aspects. McGraw-Hill Book Company, New York

WINKLER, H. G. F. - 1965 - Petrogenesis of metamorphic rocks. Springer-Verlag, New York

WINKLER, H. G. F. e V. PLATEN, H. - 1961 - Experimentelle Gesteinsmetamorphose. V. Geochim. et Cosmoch. Acta, 2A: 250 